This item was submitted to Loughborough's Research Repository by the author.

Items in Figshare are protected by copyright, with all rights reserved, unless otherwise indicated.

\title{
Stop and search in 2004: a survey of police officer views and experiences
}

PLEASE CITE THE PUBLISHED VERSION

PUBLISHER

(C) Vathek

LICENCE

CC BY-NC-ND 4.0

\section{REPOSITORY RECORD}

Qureshi, Faiza, and Graham Farrell. 2019. "Stop and Search in 2004: A Survey of Police Officer Views and Experiences”. figshare. https://hdl.handle.net/2134/779. 
STOP AND SEARCH IN 2004: A SURVEY OF POLICE OFFICER VIEWS AND EXPERIENCES

Forthcoming in the International Journal of Police Science and Management

Faiza Qureshi

Graham Farrell

Midlands Centre for Criminology and Criminal Justice

Loughborough University

Submitted April 2005, accepted September 2005. 


\begin{abstract}
The capacity to stop and search citizens is a key part of the police crime reduction repertoire. This study presents findings from a survey of all police officers at one police station in a southern English town in July 2004, looking at stop/search experiences plus a glimpse at officer views on the Criminal Justice Act 2003. The Act introduced a "major extension to the existing powers of stop and search" (Home Office cited in Keogh 2004). However, less than half of officers reported having received any formal training on the changes to stop and search procedure, and less than forty percent of officers believed that changes introduced by the Criminal Justice Act 2003 had made stop and search 'better' from their perspective. Overall, and consistent with other research, a small proportion of officers made a disproportionate amount of each of stops, searches and arrests, which could have implications for training and resource allocation. Suggestions are made for further research to examine the impact of the Criminal Justice Act 2003 upon police stops and searches, and for research to examine crime reduction effectiveness.
\end{abstract}




\section{ACKNOWLEDGEMENTS}

Though all persons and places are anonymous herein, we would like to thank all of the police officers that participated in this study. In particular we would like to thank the Chief Inspector for permission to undertake, and the Personal Assistant to the Chief Inspector for extensive cooperation with, the survey and interviews. We thank two peer-reviewers for useful comments. 


\section{INTRODUCTION}

Stop and search is an important tactic in the police crime reduction armoury. The Criminal Justice Act 2003 extended police stop and search powers to include articles concerning the commission of the offence of criminal damage. It has been suggested to be one of the most major changes to such powers since the Police and Criminal Evidence Act 1984 (see Keogh 2004; 5) which consolidated all previous stop and search legislation into one coherent Act of Parliament (Elliott and Quinn, 2003; Martin, 2003 and Slapper and Kelly 2004). This study presents findings from a survey of police officers regarding their views and experiences of stop/search and related arrests, in the wake of those changes.

In July 2004, all officers from one police station in the south of England completed a questionnaire relating to stop and search. The survey was part of a larger study that included in-depth interviews with police officers of different ranks plus analysis of police records of stop/searches that had occurred (detailed in Qureshi 2005). The survey is the focus of the present study. The next section provides context for the study by reviewing landmarks in legislation and research.

\section{BACKGROUND: POLICE STOP AND SEARCH BY 2004}

A recent review noted that "The use of stop and search powers by the police has been the most controversial issue in debates about policing ethnic minority communities” (Bowling and Phillips 2003; 534). This may always have been the situation since such powers emerged in 1824 via sections 4 and 6 of the Vagrancy Act. Under the 1824 Vagrancy Act, people could be stopped "for frequenting or loitering in a public place with intent to commit an arrestable offence”. The Act was criticised for its apparent 
disproportionate use against young black men (DeMuth, 1979 cited in Fitzgerald, 1999). Similar criticism was aimed at section 66 of the Metropolitan Police Act 1839. The 1839 Act gave police the power to stop, search, and question anyone in the Metropolitan area if there was reasonable suspicion that they were carrying stolen goods (Zander, 1999).

Despite a seemingly long history of controversy over police stop and search powers, events of the last quarter century are arguably the most compelling and well documented. In 1981, the use of stop and search powers as part of Operation Swamp in Brixton, south London, are commonly held to be a key precursor of the Brixton riots of that year. The undercover Operation Swamp resulted in 943 persons being stopped and 118 arrested (a strike rate of $12.5 \%$ arrests per stop). More than half of those stopped were black, a significantly disproportionate amount relative to the population, of whom 75 were charged (Bowling and Phillips, 2002). The Brixton riots were a major landmark in relations between the police and ethnic minority groups because, as the Metropolitan Police Service notes, the riots "were the first serious riots of the 20th century, and the first entailing substantial destruction of property since the formation of the Metropolitan Police.” (Metropolitan Police, undated).

The 1981 riots led to the appointment of Lord Scarman as head of a public inquiry. The Scarman Report (1981) suggested numerous deficiencies in the manner in which police conducted stop and search procedures. It made recommendations to improve both stop and search operations management training for Inspectors and Sergeants as well as the objective application of 'reasonable suspicion’ (The Scarman Report, 1981 
and Bowling and Phillips, 2002). A key aim of the recommendations was the improvement of relations between the police and ethnic minority communities. The Police and Criminal Evidence Act 1984 (PACE 1984), which came into force in January 1986 and has subsequently undergone revisions, is a legislative landmark. It sought to introduce safeguards against discriminatory policing and structure the use of police discretion (Brown, 1997). The requirement that a police officer have reasonable suspicion “...for suspecting that they will find stolen or prohibited articles” (s.1 (3) PACE 1984) was a critical element of PACE 1984. The concept of 'reasonable suspicion’ was intended as a safeguard in order to reduce the possibility that individuals were subject to indiscriminate or random stop and search (PACE Code of Practice, Code A, Paragraph 1.7A)).

Smith and Gray (1983), in a study preceding PACE 1984, examined the application of 'reasonable suspicion'. They observed that, when carrying out stop and search, police officers rely predominantly upon their own instincts, which could cause elements of race and class bias (Elliott and Quinn, 2002) and concluded:

\footnotetext{
"It is clear from the way that police officers talk about stops that the question of what their legal powers may be does not enter into their decisionmaking...the criterion of 'reasonable suspicion', does not act as an effective constraint on police officers in deciding whether to make a stop” (Smith and Gray, 1983 cited in Zander, 1999:162).
}

It has been debated that the concept of discretion first emerged in the criminal justice system in 1956 (Walker, 1993). This does not imply that the notion of discretion did 
not exist prior to 1956 but its impact within the criminal justice system was unclear. Kleining (1996) held discretion to encompass a normative condition of policing. It was deemed to be “a permission, privilege or prerogative to use one’s own judgment about how to make a practical determination” (op cit., 1996:83). Yet the exercise of discretion by police officers can give rise to issues of selective policing. The exercise of discretion occurs outside the supervisory purview of the police station (Bowling et al., 2004). This can provide the opportunity for police officers to exercise their discretionary powers based upon their own individual prejudices (Kleining, 1996). This becomes apparent in research that has identified police stop and search practices being driven by; age, class, gender and race (Skogan, 1990 and 1994; McConville et al., 1991; Fitzgerald and Sibbitt, 1997 and Clancy et al., 2001). Therefore, discretionary practices within stop and search that gives rise to individual prejudices of police officers is undemocratic (Kleining, 1996). This is on the basis that discretion is placed beyond public scrutiny and consent and fails to be impartial (ibid, 1996).

Formal rules delineating reasonable suspicion as a means of regulating police behaviour have a comparatively small impact upon street-level policing (Dixon et al., 1989). The regulation of police discretionary practices in stop and search could be improved in three areas (over all of which police forces have a certain degree of authority (ibid, 1989)). The use of effective police sanctions for failing to comply with police regulations, ensuring the public are aware of police powers and their rights and successful police training to change informal working practices (ibid, 1989). 
Dixon et al (1989) criticised PACE 1984 as unable to regulate the discretion of officers, due to ineffective training. This was on the proviso that the Act had failed to take into account the impact of informal working practices of police officers upon their behaviour during street-level policing (op cit., 1989 and McConville et al., 1991). Police training, it was argued, focused primarily upon law and procedure and failed to instil adequate social and interaction skills. Fitzgerald and Hale (1999 cited in Miller, Bland and Quinton, 2000) suggested public dissatisfaction with police stops would have three origins: an officer conducting a stop in an impolite fashion, whether or not an acceptable reason had been given for the stop and whether the stop was followed by a search (Fitzgerald and Hale, 1999 cited in Miller, Bland and Quinton, 2000).

Fitzgerald (1999) identified three key areas where discretion might lead to abuses of stop and search powers. The first was that legal rules underpinning stop and search could not prevent abuses of discretion; as such rules require interpretation by officers since guidelines cannot cover every eventuality -as "rules should be part of a clear and understandable framework and not liable to arbitrary re-interpretation at a later stage” (Brown, 1997:2). The second was that the concept of reasonable suspicion is highly vague and can be absent during a police stop (Quinton, Bland and Miller, 2000 and Fitzgerald, 1999). The lack of clarity regarding reasonable suspicion can lead to police officers reverting back to informal mechanisms of policing. Therefore, decisions to stop and search individuals will be based upon whether the suspect is known to the police and their 'hunches' of particular sections of the population (McConville et al., 1991). This could undoubtedly produce discriminatory policing. The third was that individuals who consent to stop/search are not provided with 
sufficient safeguards under PACE 1984, even though the Act was perceived to regulate the discretion of officers. In some circumstances, police officers may evade the requirements of reasonable suspicion and the recording of searches by claiming that the suspect consented to the search (Dixon, 1997).

Police stop and search powers were examined in the report of the Stephen Lawrence Inquiry (Macpherson, 1999). The Macpherson Report did not make direct recommendations for the amendment of stop and search powers, but focused upon increasing police accountability in the manner in which stops and searches were conducted. The aim of the recommendations was to promote trust and confidence in the use of the powers, which had been identified as a source of concern for ethnic minority communities (Miller, Bland, and Quinton, 2000). However, the Macpherson Report was perceived by some commentators as provoking the 'disproportionality debate' with the suggestion that it could "racialise every encounter between the police and the non-white public to the benefit of neither” (Ignatieff, 2000, cited in Green et al., 2000:15).

Research in the wake of the Macpherson report has begun more accurate measures of whether or not ethnic minorities are stopped in disproportionate numbers. The Home Office published a series of influential research studies covering a range of areas related to stops and searches (Bland et al. 2000a, 2000b; MVA and Miller 2000; Quinton et al. 2000; Stone and Pettigrew 2000 and Miller et al. 2000). Recent research focusing upon disproportionality has centred upon the fact that Home Office figures (since ethnic monitoring became mandatory in 1996 under s.95 of the Criminal Justice Act 1991) had consistently shown ethnic minority groups to be over- 
represented. One study suggested that, relative to the resident population, Asians are eighteen times and African-Caribbean' twenty-seven times more likely to be stopped by the police than whites (Bowling 1994 cited in Bowling and Phillips 2003). Analysis of Home Office figures suggest that between 1999 and 2003, relative to the resident population, blacks are eight times and Asians two-and-a-half times more likely than whites to be stopped by the police. The same report suggests that in the two years to 2003, the number of stops of whites fell 19\% while stops of black and Asians each increased by 28\% (Institute for Race Relation 2003; 1).

Rather than base assessments on the local resident populations, research has begun to develop measures of the 'available population'. This measures those persons who are on the street and therefore available to be stopped and/or searched, rather than just resident populations. This preliminary research has found significant differences between the two populations (MVA and Miller, 2000; Waddington 2003). The population available to be stopped and searched tended to include a greater proportion of ethnic minority groups. The 2004 study by Waddington and colleagues suggests that, at least in some areas of Slough and Reading, White people tend to be overrepresented, Asians under-represented (with some exceptions), with variation in the representation of Blacks (see also Slapper and Kelly, 2003). However, it is also the case that subsequent concerns have been raised regarding whether these groups were being legitimately targeted or not (Fitzgerald, 2003 cited in Metropolitan Police Authority Report, 2004; Bowling and Phillips 2003; 537).

A police 'stop' is defined as when a police officer requests a person to account for their actions, behaviour or possession of any article regardless of whether the person 
is on foot, driving or riding any vehicle or is a passenger in or on such a vehicle. A stop occurs when a person is asked to account for their actions or movements for investigation purposes. In order for a stop to develop into a search, officers are required to have grounds for suspicion that the individual is carrying prohibited articles or offensive weapons as defined under s.1 PACE 1984. A casual conversation is not categorised as a stop but, should it give rise to reasonable suspicion, this is grounds for a search.

The context of this research was the changes to police stop and search procedures that were introduced by the Criminal Justice Act 2003. Previously, under Section 1 of PACE 1984, police officers could only stop and search persons for "offensive weapons or prohibited articles used for the purpose of burglary or related crimes,” as per theft (s.1), taking and driving a conveyance without consent (s.12) and criminal deception (s.15), under the Theft Act 1968. The Criminal Justice Act 2003 increased police powers to stop and search persons for prohibited articles under s.1 PACE 1984 to include "an article made, adapted or intended for use in causing criminal damage," as defined under Section 1 of the Criminal Damage Act 1971. Section 1(1) of the Criminal Damage Act 1971 makes it a criminal offence for a person "to destroy or damage property belonging to another without lawful excuse if he intends to destroy or damage that property or is reckless as to whether that property would be destroyed or damaged.” Therefore, the overall effect of the Criminal Justice Act 2003 is to give police officers "the power to stop and search where they have reasonable suspicion” to suspect that a person is carrying an article to be used in the commission of criminal damage (Criminal Justice Act 2003 Explanatory Notes, Para. 10). 
By the time of and since the Criminal Justice Act 2003, the definition of the 'reasonable suspicion' required by police to initiate a stop remains a key issue. As defined under PACE 1984 there must be ‘some objective basis' for suspicion, which is not based on personal characteristics. This involves much discretion on the part of police because the 'objective' factors include: information received; someone 'acting covertly or warily' and; someone 'carrying a certain type of article at an unusual time or place' (see Sanders and Young 2003; 233). This has lead some commentators to conclude that

“Clearly, police officers have to exercise discretion in deciding whether to stop and search and arrest, for there is little objectivity in perceiving someone to be acting 'warily'. Some people look less 'suspicious' than others, and multitudes of actual or likely offences have to be prioritised”.

(Sanders and Young 2003; 233)

This assessment led the same authors to the conclusion:

"So stop and search and arrest decisions are constrained only loosely by law: the powers themselves, based on reasonable suspicion, are ill-defined and subjective; many of the offences for which the powers are defined are illdefined; and the police largely set their own priorities.”

(Sanders and Young 2003; 233) 
The context of the research is therefore, in essence, an expansion of fairly broad police discretionary powers to stop and search and arrest. In this context, the research aims are detailed in the next section.

\section{AIMS OF THE RESEARCH}

The overarching aim of the research was relatively straightforward:

To produce a snapshot of police officers' knowledge, views and experience of stop and search in summer 2004, that is, in the wake of the Criminal Justice Act 2003

The more specific aims of the study were to seek:

To shed light upon how officers define circumstances that may, or may not, result in stop and/or search;

$>$ To identify the extent and nature of any training on stop/searches since the Criminal Justice Act 2003

To identify police officers' overall opinions of the changes to stop and search.

To identify the frequency with which officers undertake stops, searches and subsequently make arrests;

To identify the nature of stops, searches, arrests, and those involved;

The following section details the survey method and administration, followed by a description of the survey of police officers and analysis of the responses to the questionnaires. 


\section{METHOD}

\section{Survey Site and Administration}

The study was conducted in a mid-size new commuter town, developed in response to the London overspill, in the south of England. The town is anonymous for present purposes. It has a population of close to 100,000, of which the 2001 census found 87.5\% were White and $12.5 \%$ from ethnic minority backgrounds. The proportion of

ethnic minorities was therefore 3.8\% higher than the national average for England and Wales.

An initial approach was made in writing to the senior officer, the Chief Inspector in charge of the police station, requesting permission to undertake the research. This was followed-up by a phone call to arrange a preliminary meeting and interview with the Chief Inspector. In turn, this led to access to interview other officers and, once a working relationship was established, to a request to conduct a survey of all police officers based at that police station. The Chief Inspector plus three more senior officers were not asked to complete the survey as they suggested they had not conducted any stop/searches in the recent past. Administrative and non-sworn staff were not included in the survey.

The survey instrument was a short self-completion questionnaire that was shown in advance to the Chief Inspector. There appear to be three factors that assisted in gaining access to all police officers. The first factor was the trust that had been established in the initial interviews. The second was the brevity of the questionnaire, as it was clear that it would not take significant amounts of time to complete and so 
would only minimally interfere with any other activities. The questionnaire took police officers, on average, less than five minutes to complete. The third factor was that it was proposed that officers would complete the survey during routine briefing sessions at the start of their shifts. This meant that a large group of officers could complete the short questionnaire in a short period of time. As a result, the overall disruption to police work was minimal - approximately ten minutes at any one briefing session. It is likely that this relatively unobtrusive procedure was influential in gaining access as well as in ensuring the high response rate that was obtained. Though the brevity of the survey questionnaire was a clear advantage for the survey administration, the resultant study would ideally be viewed as preliminary since that same brevity meant that only a few questions were asked on each topic area addressed in what follows.

The police hierarchical system was advantageous in ensuring high response rates: Police officers were told by a more senior officer to complete the questionnaires completely and honestly. The survey also carried clear instructions that all responses were anonymous. Surveys were distributed and returned at the same briefing session, thereby avoiding any possibility of respondents failing to return the questionnaire.

The first survey was conducted on $17^{\text {th }}$ July 2004 and the final follow-up from an absentee was received two weeks later on $30^{\text {th }}$ July. The bulk of the questions used pre-coded responses that required respondents to tick a box (or more than one box for multiple responses where appropriate). The station had five sections of police officers, of which one section had a preference for the questionnaire to be administered by electronic mail. In addition, the twelve officers who were absent on the days that the 
questionnaires were administered were contacted and also returned the questionnaire by e-mail. A preliminary examination of responses gave no reason to suggest that responses received by email were any different to those administered in person.

The survey response rate was 100 percent. In effect, therefore, we obtained a population rather than a sample, and so sampling error is not as issue in what follows. That is, every officer who worked from the police station below the rank of Chief Inspector, which constituted the target population, completed the survey.

\section{Overview of Survey Respondents}

The total of 70 survey responses included 54 Police Constables, 11 Sergeants (including two Acting Sergeants), and five officers of the rank of Inspector or above. In what follows the 65 responses of the Police Constables and Sergeants are presented. The reason for separating the Inspectors is that the data showed they were far less likely to have made stop/searches, almost certainly due to their greater managerial role. Only one of the five Inspectors reported having made any stops in the last five working days, which, as detailed below, is significantly different from the other ranks of police officers. ${ }^{1}$ Of the 65 officers remaining, 91\% were White, $8 \%$ Asian ( $\mathrm{n}=5)$ and there was one Black police officer. Three quarters $(75 \%)$ of these respondents were male, and all of the ethnic minority police officers were male. Excluding four non-responses, around a quarter $(n=15)$ of respondents had been in the police for one year or less, half for between two and five years $(n=30)$, and a quarter for more than five years $(n=16)$, with $10 \%$ of the total $(n=7)$ having been in the police service for more than a decade.

\footnotetext{
${ }^{1}$ It is worth noting however that the one inspector who reported having made any Stops reported having made 7 Stops. It is possible that the role of Inspectors in Stops is something that may warrant further research sometime in the future.
} 


\section{FINDINGS}

\section{How would Police Respond?}

As an introduction and a means of easing respondents gently into the survey, respondents were presented with two short written scenarios. Each scenario was followed by questions asking officers would respond to that scenario. The scenarios were not meant to be challenging, and perhaps the most important aspect of the responses is that they are reassuring in their straightforwardness. That is, the responses give confidence, in line with all other indicators, that respondents answered questions maturely and accurately. The first scenario presented to officers was:

"A man is walking down the road near where a burglary has been committed and loosely matches the description that you've been given of a suspect”.

Police officers were asked what they would do in this situation. All responded that they would stop the suspect. Slightly more than half police officers (35 of 64 respondents, 54.7\%) reported that they would stop the subject (this includes those who said they would question the suspect on the suspect's whereabouts even if the term ‘stop’ was not used). ${ }^{2}$ Slightly less than half of police officers (29 of 64 respondents, 45.3\%) reported that they would immediately conduct a search.

It was formal policy in the area in question that police officers were obliged to make a formal record of any stops. When asked how they would record the incident that resulted from the first scenario, a third of officers reported that they would record the

\footnotetext{
${ }^{2} \mathrm{~N}=64$ rather than 65 as there was 1 non-response. In stating that all officers said they would perform a Stop, this assumes that 'questioning the suspect' or similar implies a Stop even where the officers did not mention the term 'stop'.
} 
incident as a stop ( $\mathrm{n}=22$ of 64 ). The remaining two thirds reported that they would record the incident as a stop and search (Figure 1). The swing towards recording the incident being recorded as a search is likely to reflect the rather mundane fact that some officers knew they would initially stop or question the suspect but then proceed to a search.

INSERT FIGURE 1 ABOUT HERE

Officers were asked how they would respond to a second short scenario:

"You see a group of young persons who have gathered in public in the early hours of the morning and are listening to loud music, disturbing nearby residents.”

Multiple responses to the question could be recorded. Three officers (4.6\%) said they would take no action. Most officers $(87.7 \%, \mathrm{n}=57)$ said they would ask the youths 'to move on'. Just over a quarter of officers ( $n=17$, of whom 12 had also said they would ask the youths to move on) said they would take another type of action, of which the most common types were asking the youths to turn down the volume ( $\mathrm{n}=6$ or $9.2 \%$ ), and taking the details of the youths ( $\mathrm{n}=5$ or $7.7 \%$ ). Three officers said they would 'stop' the youths, and one officer said they would confiscate the stereo and advise them that they could collect if from the police station (presumably the next day). 
Nearly three quarters of officers $(72.3 \%, n=47)$ said they would record the incident resulting from this scenario as a stop, $6 \%(n=4)$ said they would record it as a stop/search, with $18.5 \%(\mathrm{n}=12)$ saying they would record it in 'another' category. Half of these said they would take no further action or that it was not a police matter, and the remainder said they would give a warning, report to the matter to a supervisor or local officials, or record it in their pocket book.

The findings from the initial questions regarding officers' perception of two scenarios largely conformed to expectation. As noted, the main contribution of these questions was to gently introduce respondents to the survey while providing some indirect evidence regarding the quality and overall validity of responses.

\section{Training on Stop and Search}

Police officers were asked if they had any training related to stop and search in the twelve months prior to completing the survey (July 2004). This would capture training covering a four-month period prior to the Criminal Justice Act 2003 and the following eight months. ${ }^{3}$ The overall finding suggested some confusion: $46 \%$ said they had received training, 40\% said they had not, and 14\% said they did not know if they had received any training on stop and search (Figure 2).

\section{INSERT FIGURE 2 ABOUT HERE}

The 30 officers who had received training on stop/search were asked about the format of the training. They could report having received training by more than one method.

\footnotetext{
${ }^{3}$ The Criminal Justice Act 2003 received Royal Assent and came into force on $20^{\text {th }}$ November 2004.
} 
Two thirds of officers who had received training reported having received 'formal classroom instruction', and 60\% reported having received training at their daily briefing session (Figure 2), of whom around half $(n=9)$ reported having received both these types of training. It is possible there is some double-counting here if officers counted briefing sessions as a type of formal classroom training. The one officer who reported having received training as a 'practical' presumably received this on the beat from another officer. Close to a third of officers who received training, or $16 \%$ of all police officers at the police station, reported having received training via published guidelines.

When asked how many hours of training they had received, of those who responded ( $n=26$ ) more than half of officers said they had received one hour or less training. All except two respondents reported receiving less than 6 hours training. The exceptions were one sergeant who reported undertaking additional study on their own and an officer who reported having received 'practical' training (which we presume was on the beat), who reported having received it over a 3-day period.

\section{Officers Views on Change due to the Criminal Justice Act 2003}

Police officers were asked for their views on the Criminal Justice Act 2003.

Specifically, they were asked whether they thought the Criminal Justice Act 2003 has "been better, about the same, or not as good" in relation to stop and search for “prohibited articles concerning criminal damage.” Of the 62 valid responses, more than a third of officers thought the Act was better ( $n=24$ or $38.7 \%$ ), the same number thought it was about the same ( $n=24$ or $38.7 \%)$. Only one in five officers $(n=14$ or 22.6\%) thought that the Act was 'not as good'. There was a reasonable spread of 
responses and no real evidence that, from the perspective of these police officers, the Criminal Justice Act made a substantial improvement in stop/search.

Taken at its most critical, the survey suggests that most police officers at this police station did not perceive an improvement in stop and search procedures after the Criminal Justice Act 2003. There may well be a need for further research on this issue, which was not possible here due to the study's brief and exploratory nature. The bulk of the remaining analysis focuses upon the frequency and nature of stops searches and arrests.

\section{The Frequency and Distribution of Stops, Searches and arrests}

How Many Stops?

Police officers were asked how many stops they had made in the last five working days. Four respondents reported that they were not on street duty. There were three ambiguous responses where a range was given, in which case the lowest number in the range was used to produce a conservative result. ${ }^{4}$

Many criminological phenomena, like social phenomena in general, are very unevenly distributed. Well-known criminological examples include the fact that a few frequent offenders commit a disproportionate amount of crime, a few repeat victims experience a disproportionate amount of crime, and a few hot spots are where a disproportionate amount of crime takes place. Police stops are no exception to this rule. The 61 police officers that were on street duty reported having made a total of 443 stops in the last 5

\footnotetext{
${ }^{4}$ The choice of the midpoint or high value would have made little difference due to the narrow ranges: In two instances the range of Stops given was '8-10' and '16-17' while the third respondent wrote "Not sure - more than 1” (and so a value of 2 Stops was used for this case).
} 
working days. However, this includes double counting where officers worked together: officers tended to work in pairs but sometimes on their own depending on the staff available during a particular shift. Consequently, a crude approximation of the actual number of stops would be half the total of 443 . The 443 stops is an average of 7.26 stops per officer over five day periods in or around July 2004. However, this average masks the underlying skewed distribution shown in Table 1. Of the 61 officers on street duty, $11 \%(n=7)$ did not make any stops in their last five working days. At the other extreme, one officer made 17 stops. The most prolific seven officers accounted for 110 stops in their last five working days, that is, $11 \%$ of police made $25 \%$ of all stops. Clearly the possible influence of double counting suggests a need to verify the nature of this distribution (and those described for searches, below) via an examination of official records.

The skewed distribution of a small proportion of police officers accounting for a significant percentage of stops could be due to variations arising from police beats. In one area of London examined by Fitzgerald and Sibbitt (1997) twenty-uniformed patrol teams accounted for 0-25 stops within one month. Yet in another area of London, the minimum number of stops conducted by one beat was 212 compared to another, which accounted for 1784 (op cit., 1997). The Commission for Racial Equality Working Group analysed one division of the Metropolitan Police Service (see Fitzgerald and Sibbitt, 1997). Of 46 prominent nominals (individuals known to the police) six had been stopped twenty-five times or more. The average number of stops was 8 times (op cit., 1997).

INSERT TABLE 1 ABOUT HERE 
Though six ethnic minority police officers is too small a number to draw any particular conclusions, each of these officers made at least eight stops in the last five working days. This preliminary analysis did not suggest any difference in the likelihood of making a stop according to the sex of officer, with two-thirds of both sexes (66.7\% of female and $67.4 \%$ of male officers) having made 5 or more stops in the last five working days, with similar proportions of each sex throughout the distribution of stops.

\section{How Many Searches?}

With four of the 65 respondents not on street duty, and seven not reporting having made any stops in the last 5 working days this left 54 officers who had made at least one stop. Each of these stops could, in theory, have proceeded to include a search. The 54 officers reported a total of 248 searches, an average of 4.6 searches in the last five working days (Table 2). Again, there is the possibility of double counting of searches where officers were not working alone. However, if the 443 stops produced 248 searches, this suggests a 0.56 probability or $56 \%$ average chance of a search at any given stop. This average number of searches also masks a skewed distribution. Of officers making a stop, 93\% $(n=50)$ conducted at least one search. Of those who made a stop, around half (52\%) made three or less searches. At the other extreme, the most prolific searcher had conducted 15 searches in the previous 5 working days, while half of all searches were conducted by $20 \%$ of police officers. 
Research by Fitzgerald (1999) publicized three factors that play a crucial role in shaping the pattern of searches. Police officers target certain individuals based upon their own perceptions of who is involved in crime. This is instrumental in assisting in police intelligence and increases the chances of a successful search leading to an arrest (see Young, 1994 cited in Miller et al., 2001). Next, police officers held that searches are a proactive means of dealing with local crime problems. Through directing police activity in hot spot areas, criminal activity can be disrupted to a certain extent (see Jordan, 1998 cited in Miller et al., 2001). Finally, the power to stop and search has been viewed by some police officers as indicative of measuring their performance outside the supervisory scope of the police station (Fitzgerald, 1999) (see also Fitzgerald and Sibbitt, 1997). These factors could provide an insight into the skewed distribution of searches conducted by police officers in this study.

\section{How Many Arrests?}

Six in ten of all officers (59\%, $n=36$ of 61 ) reported having made at least one arrest as the result of a stop in the last five working days, for a total of 140 arrests. Of those officers who had made a stop and search, $72 \%$ ( $n=36$ of 50 ) had made an arrest as a result. While the average for all officers on street duty was therefore an average of 2.3 arrests each, that average rose to 3.9 each for officers who made any arrests. Like stops and searches and many phenomena, the distribution of arrests is skewed (Table 3). Of the 36 officers making at least one arrest as the result of a stop, over a quarter $(n=10)$ made only one arrest. One officer reported having made 12 arrests as the result of stops in the last five working days, and two officers reported 10 arrests. The $8 \%$ of officers who made most arrests $(n=5)$ accounted for more than a third of all arrests (35.7\%, 50 arrests). 
INSERT TABLE 3 ABOUT HERE

\section{Strike Rates and Measures of Distribution}

The officers in the study reported having made 443 stops, 248 searches and 140 arrests in the last five working days. While strike rates will vary significantly between officers, reflecting the overall unequal distributions shown previously, this gives average strike rates of

- 0.56 searches per stop

- 0.32 arrests per stop

- 0.56 arrests per search

The strike rate for arrests per stop appears significantly greater than that found elsewhere (see e.g. Waddington et al. 2004, Table 4). Literature relating to the strike rate of 'successful' searches that lead to an arrest is relatively small. Less than one in ten searches result in an arrest (Cragg, 1999 cited in Slapper and Kelly, 2003 and Reiner, 2000). In 2003/04 national statistics for England and Wales revealed that only $13 \%$ of searches led to an arrest (Murray and Fiti, 2004). Although there has been no variation in the proportion of arrest rates since 1999/00, this is the highest rate since 1993 (ibid, 2004)

We offer no explanation here for this apparently high strike rate. One anonymous peer-reviewer suggested the finding might call into question the accuracy of officers' responses. However, separate questions on the number of stops, searches and arrests 
were asked in sequence, so there is no reason to suspect any particular bias (particularly any deliberate bias). Further, it is unclear how such a bias would manifest itself: would officers under-state stops or over-state arrests? The anonymous questionnaire was short and answered in a single session, and we sincerely doubt that officers had time or motivation to introduce any calculated bias.

In relation to quantitative assessment of the distribution of stops, searches, and arrests, the Lorenz curve and Gini coefficient were examined for each. The Lorenz curve and Gini coefficient are popular means of exploring unequal distributions among a population. They are most commonly used to show the unequal distribution of wealth. The Lorenz curves illustrate (Figure 3) and the Gini coefficients quantify (Table 4) the extent to which arrests are more unevenly distributed than searches, which in turn are more unevenly distributed than stops.

\section{INSERT FIGURE 3 ABOUT HERE (LORENZ CURVES) INSERT TABLE 4 ABOUT HERE (GINI COEFFICIENTS)}

The Lorenz curves are a plot of cumulative frequency distributions whereby divergence from the diagonal line of equality demonstrates inequality. Hence in Figure 3, the curves are increasingly further from equality for stops, then searches, then arrests. The Gini coefficient measures the proportion of the area between equality and the curve, and takes a value between 0 and 1 . A Gini coefficient of zero would demonstrate complete equality (say, if each police officer made the same number of stops). A Gini coefficient with a value of 1 would demonstrate complete inequality (if one officer made all of the stops). As would be expected, the inequality 
of distribution among officers increases from stops to searches to arrests since fewer officers become 'eligible’ each time. That is, only those officers who make stops can make searches, and only those offices that undertake searches are likely to make arrests.

\section{The Nature of the Stops and Searches}

Officers were asked more specific questions about the last stop and search they had conducted, regardless of whether it was in the last five working days. Males were stopped in $86 \%$ of cases (see Fitzgerald et al., 2002). However, women police officers were more likely to have stopped a woman suspect. Half of women officers reported a stop and search with a woman suspect compared to only $2 \%$ of male officers ( 1 officer). This reflects the fact that officers are generally advised not to search different-sex suspects, and are not allowed to be present for different-sex suspects when any items of clothing are removed. ${ }^{5}$

\section{INSERT TABLE 5 ABOUT HERE}

During the most recent stop/searches conducted by officers in the study, 83\% $(n=54)$ involved White suspects, $14 \%$ Asian suspects ( $\mathrm{n}=14$ of which 13 were Southwest Asian and one Southeast Asian), and two (4\%) involved Black suspects. Officers were requested to report the self-defined ethnicity of the suspect. One of the ethnic minority suspects was searched by a non-white police officer, which, to the extent it can be

\footnotetext{
${ }^{5}$ PACE 1984 Codes of Practise section A3.6 states that any search involving more than the removal of a person's outer coat, jacket, gloves, footwear or headgear must be carried out by an officer of the same sex as that person being searched. In such incidents, this cannot be carried out in the presence of anyone of the same sex, unless the person being searched specifically requests it (an appropriate adult for example). Even for searches where only gloves, outer coat or jacket are removed it is considered a better option that a search is conducted by the same sex so as to reduce any likelihood of any allegations of assault being made against the searching officer.
} 
determined from the small study size, is in keeping with the proportion of non-white police officers.

Officers were asked to record the grounds for suspicion on which the stop and search was based. They were allowed multiple responses so that, with two missing cases, a total of 87 reasons were given for the 63 stop and searches (Figure 4). By far the most frequent grounds for suspicion were that a person fitted the description of a suspect, followed by the fact that a person was around in the small hours of the morning.

\section{INSERT FIGURES 4 AND 5 ABOUT HERE}

The object of searches that were conducted varied significantly. Again, multiple responses were allowed since a search could have more than one object. A total of 88 search objects were given by the 65 police officers (Figure 5).

\section{DISCUSSION AND CONCLUSIONS}

This chapter detailed the method of, and findings from, a small-scale study of police officers working from one police station in a southern English town. This section discusses the key methodological and substantive contributions of the study.

Methodologically, the survey’s 100 percent response rate is relevant for police research. It indicates the success of using short self-completion questionnaires administered during briefing sessions under the auspices of a senior officer. Further, the electronic mail follow-up with individual officers proved a remarkably successful means of catching any absentees. The extensive use of e-mail in policing presents, in 
this domain as elsewhere exciting possibilities for widespread self-completion electronic surveys.

There are some acknowledged methodological limits to aspects of the analysis. Some double counting of stop/searches would inevitably occur because the data was reported at the level of individual officers rather than patrol-pairs. However, this is not an issue in those parts of the study that relate to officers' views on stop/search and experiences of training. It is likely that future research based on analysis of official records will be able to verify or refute the preliminary patterns revealed herein.

The skewed distribution of stops and searches is evident and has been recognised elsewhere. ${ }^{6}$ There is, of course, a huge variation in police work. Different assignments in different places and different times of the day, week or year, will produce different likelihoods of an encounter that may result in a stop. Nevertheless, if some officers disproportionately undertake stops, there is further support for examining these hotstoppers more closely. If a small number of officers have a disproportionate role in this type of contact with the public, there may be commensurately disproportionate benefit if these officers can be identified and given any additional advice, training or assistance they may require. It has previously been suggested that monitoring frequent stoppers, particularly those officers who frequently stop citizens from ethnic minority groups, could be a productive means of monitoring proportionality in stops (MVA and Miller 2000). It is possible that focused interventions and further training could be

\footnotetext{
${ }^{6}$ Professor P.A.J. Waddington confirmed that in his work with Kevin Stenson (see e.g. Waddington et al. 2004), they also found, but did not publish the findings relating to, a highly skewed distribution of stops among officers (personal communication, 2005).
} 
developed based around officers who are hot-stoppers, just as police prevention policies are targeted at repeat offenders, repeat victims and geographical hot-spots. ${ }^{7}$

A snapshot of stops occurring over a five-day time-window does not necessarily mean that the patterns found here will be replicated over a longer period. However, the tendency towards such distributions that are evident in many social phenomena suggests that a similar skewed distribution will be likely to emerge if further research was able to examine a longer reference period. Indeed, there is some reason to believe the distribution may be more skewed when a longer period of time is examined (see e.g. Farrell et al. 2002). Other possibilities present themselves: Officers previously assessed as particularly outstanding in dealing with tricky encounters with the public might reasonably be allocated to those times and places where the potential for stop/searches is likely to be high.

It is possible that the skewed distribution of stop/searches found herein is an artefact of the survey's reference period. With changes in shifts and resources over time, it is possible that stop/searches become more evenly distributed across officers. However, what we know from most other social phenomena suggests that the opposite may well be true and that the true patterns are even more skewed than those revealed herein. Either way, there is an exciting potential for further empirical study of the phenomenon that has potential implications for police training and resource allocation policies relating to stop/search. The study of the uneven distribution nature of such phenomena has proved a fruitful line of enquiry in many areas including other areas of policing and, at the very least, warrants closer study.

\footnotetext{
${ }^{7}$ The comparison here is the common use of skewed distributions as an efficient means of allocating resources. It should not be misinterpreted as comparing frequent-stop police officers to repeat offenders.
} 
The expansion of police stop/search powers introduced by the Criminal Justice Act 2003 has been suggested to be the most significant since PACE 1984 (Slapper and Kelly, 2004). Stop and search power is an important tool in the police crime reduction repertoire. Put another way, crime reduction is a primary raison d'etre of stop and search. Though it may work primarily via an indirect deterrent effect, stop and search has a direct crime reduction effect. This occurs where offenders are apprehended, disrupted or disturbed, in the antecedence or wake of a crime, where a 'wanted' suspect is apprehended, or where a crime is found to be in commission at the time of the stop (by possession of illegal products, for example). However, the impact of stop and search upon crime has a tendency to become lost in the ongoing debates relating to equity in implementation. The debate would be significantly informed by quality research that examined effectiveness in crime reduction. Such research would be difficult, but estimates of crimes prevented or avoided might possibly be derived from criminal career research. Predicting the likely costs of crime averted by arrests would be one possibility, and could perhaps be derived from the existing empirical resources of criminal career research.

The main worry in the expansion of police stop and search powers is an implementation issue relating to equity: If expanded stop/search powers lead to racial bias in their implementation then this cost to society could outweigh any potential benefit from crime reduction. The current study’s size means that analysis of racial aspects is difficult (cell case sizes rapidly becoming small for analysis that included ethnicity as a variable for either police officers or suspects). However, there are no initial indicators of such bias in the stops made by officers of different ethnic 
backgrounds, or in the ethnic composition of suspects. Clearly there is a need for further research to either verify or refute these indicators, and these should be viewed as preliminary measures.

A potentially useful further avenue of exploration would be an examination of police records of stops and searches to determine whether or not there was a change in stops and searches in the aftermath of The Criminal Justice Act 2003. The present study only provided a snapshot after the Act. Retrospective analysis of police records could be used to construct a quasi-experimental-type assessment. A suitable comparison group could be constructed from data for the same areas in previous time periods. If there is a change in the frequency and/or nature of stops then there is a need to identify its cause and effect. If there is no such change, then exploring the reason for its absence is similarly important if it is the case that the Criminal Justice Act 2003 represented a 'major extension to the existing powers of stop and search' (Home Office, cited in Keogh 2004; 5). Initial investigation of record data for the police station examined here suggests significant change in the extent and nature of stop/search (see Qureshi 2005). As a preliminary study, however, the present work will have achieved its aim if it makes an incremental addition to the knowledge base relating to police stop/search powers in the wake of the Criminal Justice Act 2003. 


\section{REFERENCES}

Bland, N., Miller, J. and Quinton, P. 2000. Upping the PACE? An Evaluation of Recommendations of the Stephen Lawrence Inquiry Report on Stops and Searches. Police Research Series Paper 128. London: Home Office.

Bland, N., Miller, J. and Quinton, P. 2000. Managing the Use and Impact of Searches: A Review of Force Interventions. Police Research Series Paper 132. London: Home Office.

Bowling, B. and Phillips, C. 2002. Racism, Crime and Justice. London: Longman.

Bowling, B. and C. Phillips with the assistance of A. Shah. 2003. 'Policing ethnic minority communities' in T. Newburn (Ed.) Handbook of Policing. Devon: Willan Press (pp. 528-555).

Bowling, B., Phillips, C., Campbell, A., and Docking M. 2004. Policing and Human Rights: Eliminating Discrimination, Xenophobia, Intolerance and the Abuse of Power from Police Work. Identities, Conflict and Cohesion Programme Paper Number 4. Switzerland: United Nation Research Institute for Social Development.

Clancy, A., Hough. M., Aust, R., and Kershaw, C. 2001. Crime, Policing and Justice: The Experience of Ethnic Minorities - Findings from the 2000 British Crime Survey. Home Office Research Study 22. London: Home Office. 
Cragg, 1999. 'Stop and Search Powers: Research and Evaluation'. Cited in Slapper, G., and Kelly, D. 2003. The English Legal System (6 ${ }^{\text {th }}$ Edition). London: Cavendish Publishing.

Criminal Damage Act 1971.

Criminal Justice Act 2003 Explanatory Notes (online at http://www.hmso.gov.uk/acts/en2003/2003en44.htm ).

Dixon, D., Bottomley, A.K., Coleman, C. A., Gill, M. and Wall, D. ' Reality and Rules in the Construction and Regulation of Police Suspicion'. International Journal of the Sociology of Law, 1989, Volume 17(3), pp 345-362.

Dixon, D. 1997. The Law in Policing: Legal Regulation and Police Practice. Oxford: Claredon Press.

Elliott, C., and Quinn, F. 2002. The English Legal System (4 ${ }^{\text {th }}$ Edition). Essex: Pearson Educational Limited.

Farrell, G. W. H. Sousa and D. Lamm Weisel. 2002. 'The time-window effect in the measurement of repeat victimization: a methodology for its measurement and an empirical study’ in N. Tilley (Ed.), Analysis for Crime Prevention, Crime Prevention Studies, 13, 15-27. 
Fitzgerald, M., and Sibbitt, R. 1997. Ethnic Monitoring in Police Forces: A

Beginning. Home Office Research Study No. 173. London: Home Office.

Fitzgerald, M. 1999. Final Report into Stop and Search. London: Metropolitan Police Service.

Fitzgerald, M., and Hale, C. 1999. Stops, Searches and Limitations of Ethnic Data.

Cited in Fitzgerald, M. 1999. Final Report into Stop and Search. London:

Metropolitan Police Service.

Fitzgerald, M., Hough, M., Joseph, I., and Qureshi, T. 2002. Policing for London. Devon: Willan Press.

Green, D. G., French, J., Grieve, J., Ignatieff, M., O’Brien, M. and Skidelsky, R. 2000. Institutional Racism and the Police: Fact or Fiction? London: Institute for the Study of Civil Society (at http://www.irr.org.uk/pdf/cjs_briefing_2003.pdf ).

Institute for Race Relations. 2003. 'Race and the Criminal Justice System’ Institute for Race Relations Briefing Paper, 26 March. London: Institute for Race Relations.

Keogh, A. 2004. Criminal Justice Act 2003: A Guide to the New Law. London: Law Society Publications.

Kleining, J. 1996. The Ethics of Policing. Cambridge: Cambridge University Press. 
McConville, M., Sanders, A., and Leng, R. 1991. The Case for the Prosecution. London: Routledge.

Macpherson, W. 1999. The Stephen Lawrence Inquiry: Cmd 4262-I. London: Home Office.

Martin, J. 2003. The English Legal System (3 ${ }^{\text {rd }}$ Edition). Essex: Pearson Educational Limited.

Metropolitan Police Service. Undated. 'Brixton Riots, 1981’ at

http://www.met.police.uk/history/brixton_riots.htm (accessed December 2004).

Metropolitan Police Authority. 2004. Report of the MPA Scrutiny on MPS Stop and Search Practice. London: Metropolitan Police Authority.

Miller, J. 2000. Profiling Populations available for Stops and Searches. Police Research Series Paper 131. London: Home Office.

Miller, J., Bland N., and Quinton, P. 2000. The Impact of Stops and Searches on Crime and the Community. Police Research Series Paper 127. London: Home Office.

Miller, J., Bland, N., and Quinton, P. ‘A Challenge for Police-Community Relations: Rethinking Stop and Search in England and Wales’ European Journal on Criminal Policy and Research. 2001, Vol. 9, pp71-93. 
Mooney, J., and Young. J. 1999. Social Exclusion and Criminal Justice: Ethnic Minorities and Stop and Search in North London. Middlesex: Middlesex Centre for Criminology.

Murray, L., and Fiti, R. 2004. Arrests for Notifiable Offences and the Operation of Certain Police Powers under PACE: England and Wales, 2003/04. Home Office Statistical Bulletin 18/04. London: Home Office.

MVA, and Miller, J. 2000. Profiling Populations Available for Stops and Searches. Police Research Series Paper 131. London: Home Office.

Qureshi, F. A. 2005. 'The Impact of Extended Police Stop and Search Powers under the Criminal Justice Act 2003: An Evaluation of a Southern Town’, Paper presented to the British Society of Criminology, University of Leeds, July 2005.

Quinton, P., Bland, N . and Miller, J. 2000. Under Suspicion: Police Stops, DecisionMaking and Practice. Police Research Series Paper 130. London: Home Office.

Reiner, R. 2000. The Politics of the Police ( $3^{\text {rd }}$ Edition). Oxford: Oxford University Press.

Sanders, A. and R. Young. 2003. 'Police Powers' in T. Newburn (Ed.) Handbook of Policing. Devon: Willan Press (pp. 228-258). 
Scarman, Lord. 1981. The Brixton Disorders 10-12 April 1981: Report of an Inquiry. London: Home Office.

Skogan, W. 1990. The Police and the Public in England and Wales. Home Office Research Study Number 117. London: Her Majesty’s Stationery Office.

Skogan, W. 1994. Contacts between the Police and the Public: Findings from the 1992 British Crime Survey. Home Office Research Study Number 134. London: Her Majesty’s Stationery Office.

Slapper, G., and Kelly, D. 2003. The English Legal System ( $6^{\text {th }}$ Edition). London: Cavendish Publishing.

Slapper, G., and Kelly, D. 2004. The English Legal System ( th $^{\text {th }}$ dition). London: Cavendish Publishing.

Stone, V. and N. Pettigrew. 2000. The Views of the Public on Stops and Searches. Police Research Series Paper 129. London: Home Office.

Waddington, P. A. J. 2003. Keeping Stop and Search in Proportion. Cited in: Police Magazine November 2003:pp17-19.

Waddington, P.A.J., K. Stenson and D. Don. 2004. 'In Proportion: Race, and police stop and search’ British Journal of Criminology, 44, 889-914. 
Walker, S. 1993. Taming the System: The Control of Discretion in Criminal Justice 1959-1990. Oxford: Oxford University Press.

Zander, M. 1999. Cases and Materials on The English Legal System ( $8^{\text {th }}$ Edition). London: Butterworths. 


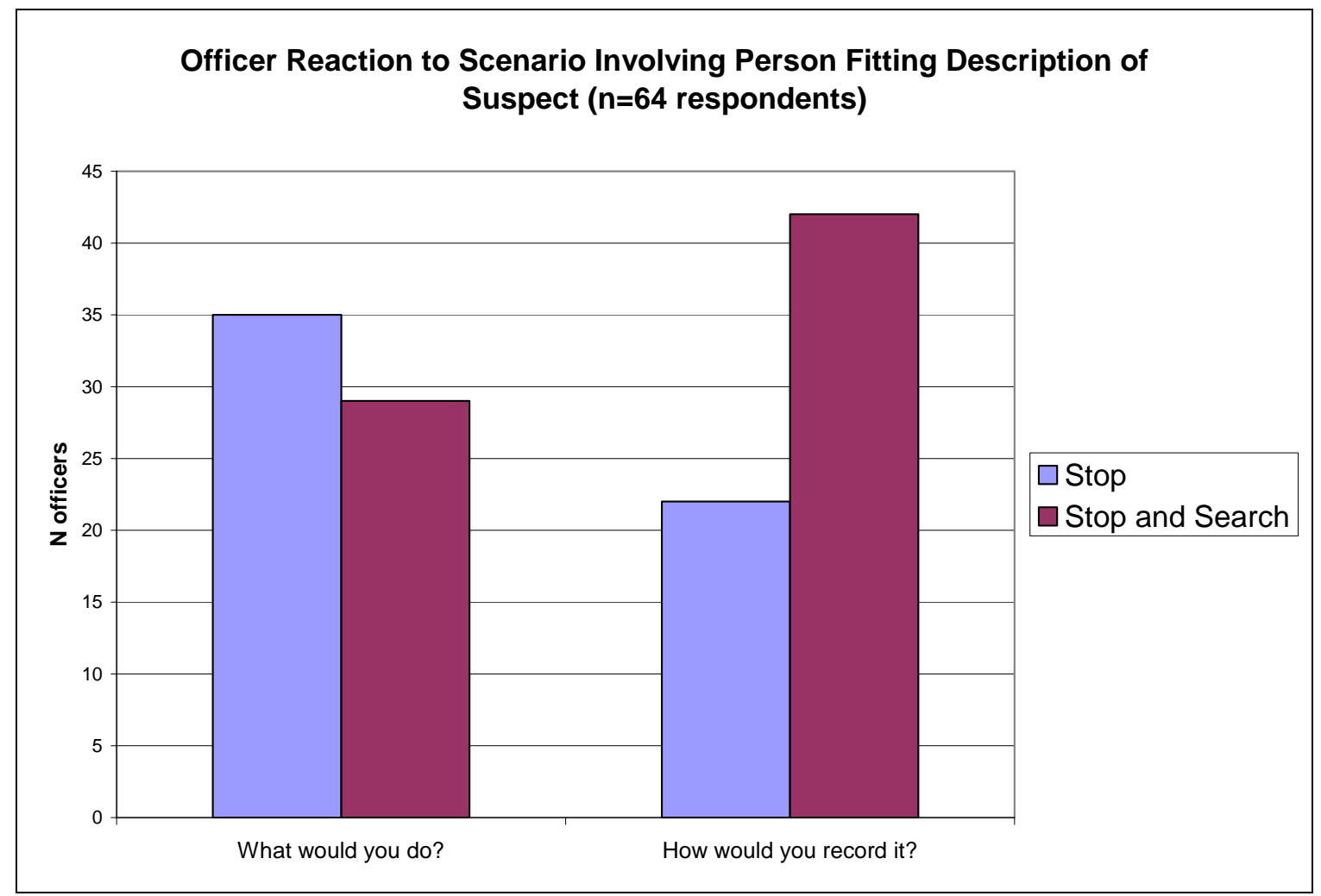

Figure 1

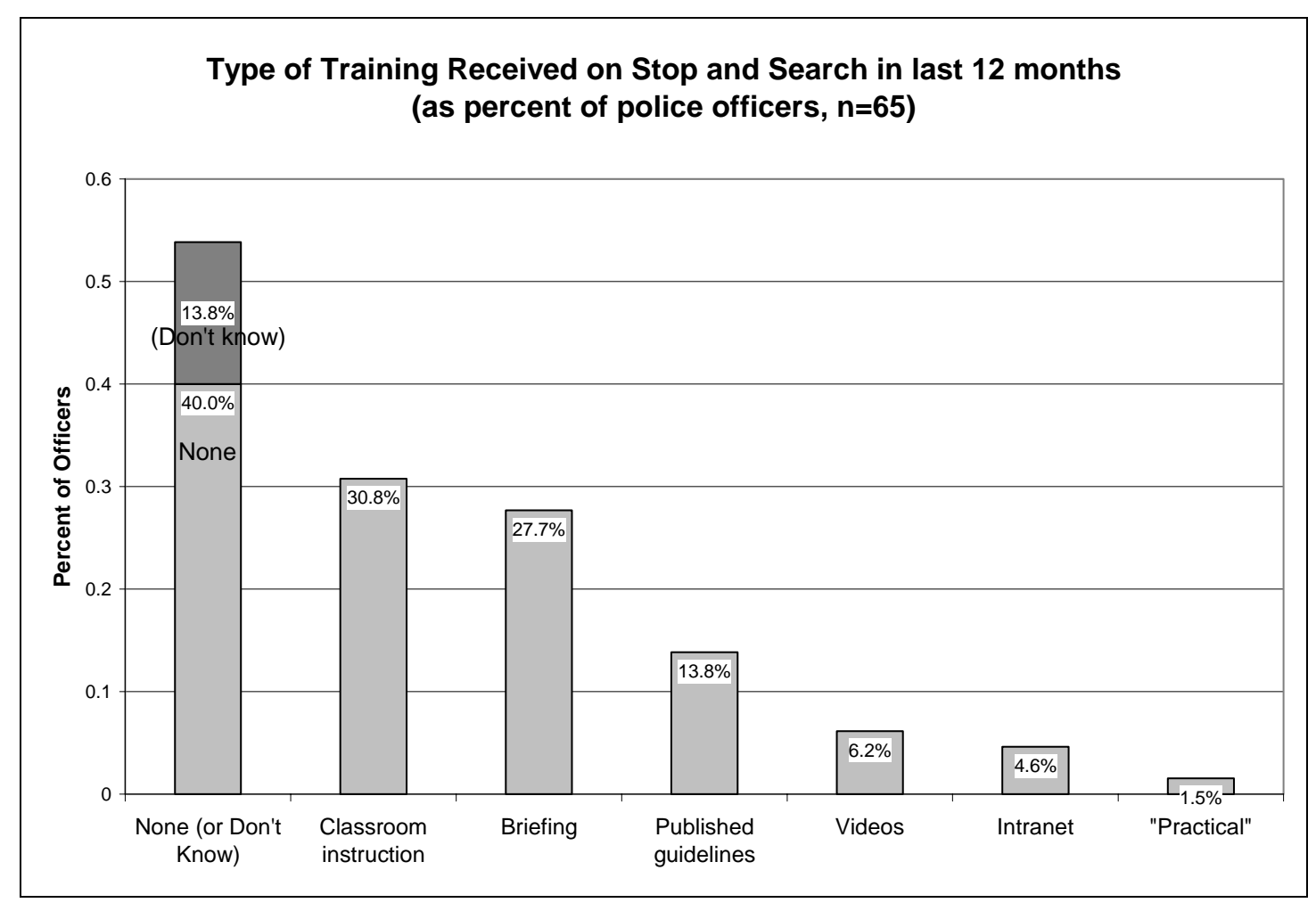

Figure 2 


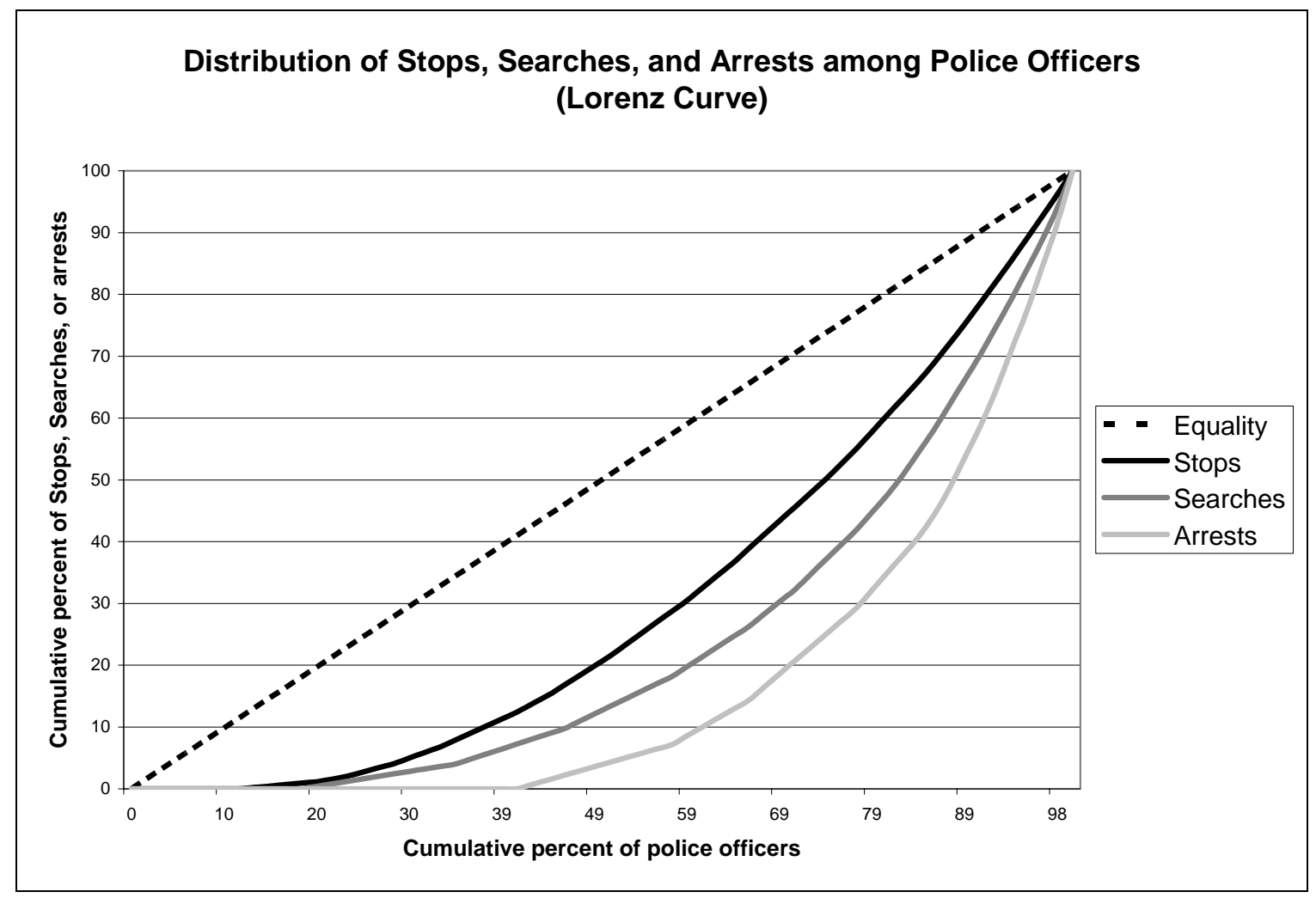

Figure 3

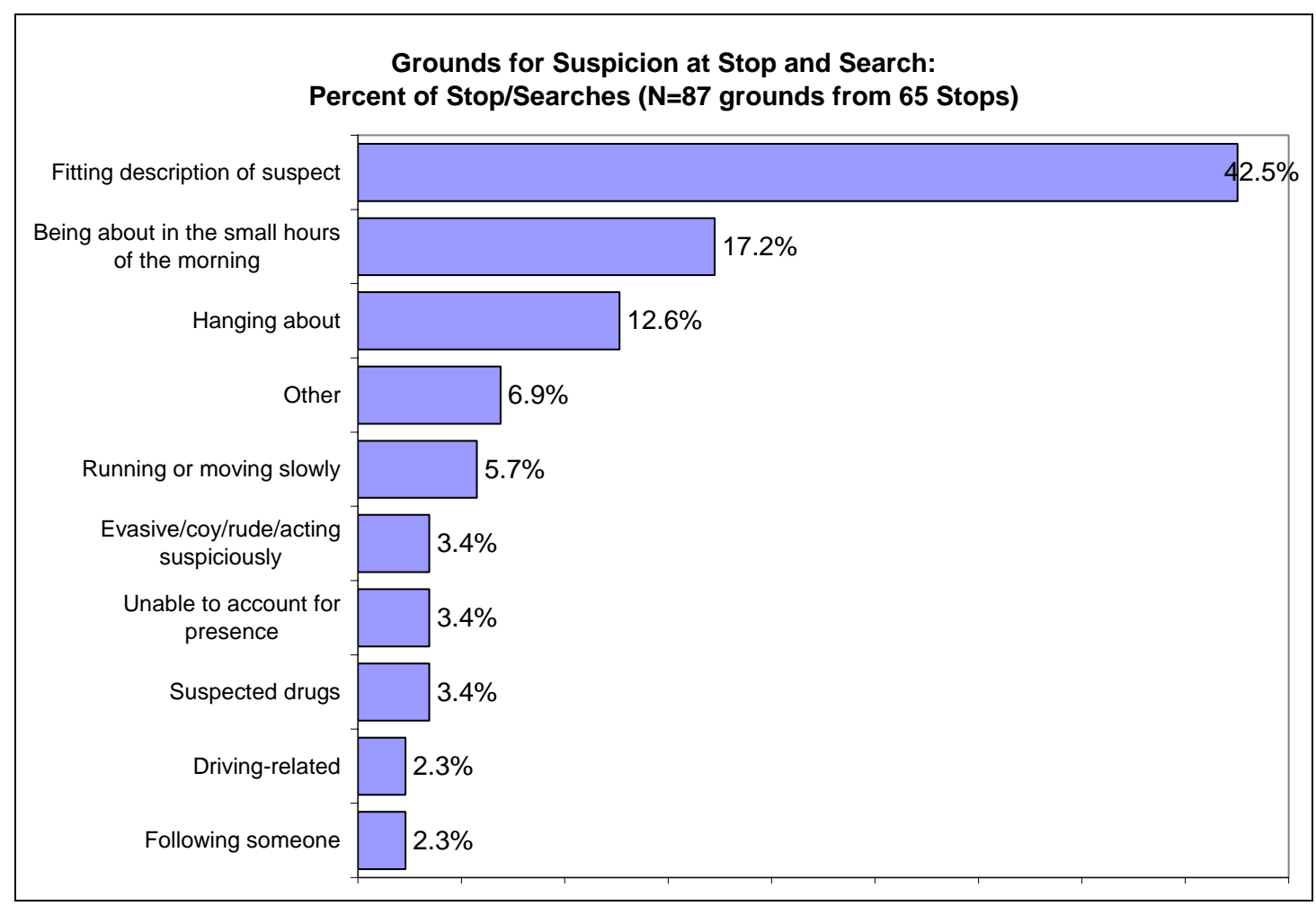

Figure 4 


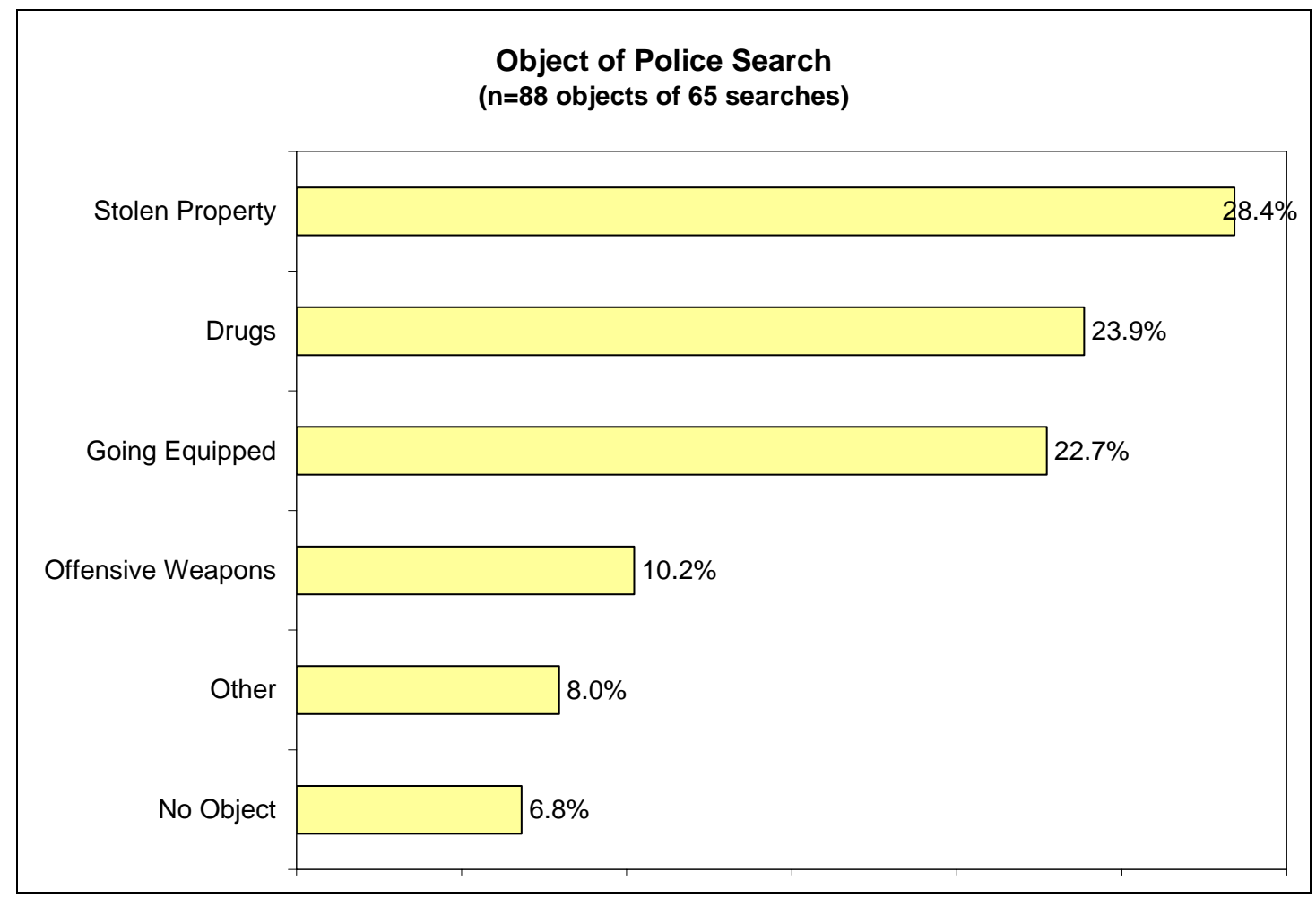

Figure 5

Table 1: Stops by Police Officers in Last 5 Working Days

\begin{tabular}{|c|r|r|r|r|}
\hline \multirow{2}{*}{\begin{tabular}{l} 
oftops per \\
\cline { 2 - 5 }
\end{tabular}} & \multicolumn{2}{|c|}{ Police Officers } & \multicolumn{2}{c|}{ Stops } \\
\hline 0 & & $\begin{array}{c}\text { Cumulative } \\
\text { \% }\end{array}$ & $\mathbf{N}$ & $\begin{array}{c}\text { Cumulative } \\
\text { \% }\end{array}$ \\
\hline 1 & 7 & 11.5 & 0 & 0.0 \\
\hline 2 & 5 & 19.7 & 5 & 1.1 \\
\hline 3 & 2 & 23.0 & 4 & 2.0 \\
\hline 4 & 3 & 27.9 & 9 & 4.1 \\
\hline 5 & 3 & 32.8 & 12 & 6.8 \\
\hline 6 & 5 & 41.0 & 25 & 12.4 \\
\hline 7 & 2 & 44.3 & 12 & 15.1 \\
\hline 8 & 4 & 50.8 & 28 & 21.4 \\
\hline 9 & 5 & 59.0 & 40 & 30.5 \\
\hline 10 or more & 3 & 63.9 & 27 & 36.6 \\
\hline Total & 22 & 100.0 & 281 & 100.0 \\
\hline Not & 61 & & 443 & \\
\hline
\end{tabular}

Notes:

1. The 4 officers who were 'Not on Street Duty' were excluded from Table 1.

2. These are the reports of individuals whereas officers often worked in pairs, so the table includes double-counting where two officers reported the same Stop. 
Table 2: Searches by Police Officers in Last 5 Working Days

\begin{tabular}{|c|c|c|c|c|}
\hline & \multicolumn{2}{|c|}{ Officers } & \multicolumn{2}{|c|}{ Searches } \\
\hline $\begin{array}{c}\text { Searches } \\
\text { per } \\
\text { Officer }\end{array}$ & $\mathbf{N}$ & $\begin{array}{c}\text { Cumulative } \\
\%\end{array}$ & $\mathbf{N}$ & $\begin{array}{c}\text { Cumulative } \\
\%\end{array}$ \\
\hline 0 & 4 & 7.4 & 0 & 0.0 \\
\hline 1 & 10 & 25.9 & 10 & 4.0 \\
\hline 2 & 7 & 38.9 & 14 & 9.7 \\
\hline 3 & 7 & 51.9 & 21 & 18.1 \\
\hline 4 & 5 & 61.1 & 20 & 26.2 \\
\hline 5 & 3 & 66.7 & 15 & 32.3 \\
\hline 6 & 4 & 74.1 & 24 & 41.9 \\
\hline 7 & 2 & 77.8 & 14 & 47.6 \\
\hline 8 & 1 & 79.6 & 8 & 50.8 \\
\hline 9 & 2 & 83.3 & 18 & 58.1 \\
\hline 10 or more & 9 & 100.0 & 104 & 100.0 \\
\hline Total & 54 & & 248 & \\
\hline
\end{tabular}

Table 3: Arrests by Police Officers in Last 5 Working Days

\begin{tabular}{|r|r|r|r|r|}
\hline \multirow{2}{*}{$\begin{array}{c}\text { Arrests } \\
\text { per } \\
\text { officer }\end{array}$} & \multicolumn{2}{|c|}{ Officers } & \multicolumn{2}{|c|}{ Arrests } \\
\cline { 2 - 5 } & $\mathbf{N}$ & $\begin{array}{c}\text { Cumulative } \\
\text { \% }\end{array}$ & $\mathbf{N}$ & $\begin{array}{c}\text { Cumulative } \\
\text { \% }\end{array}$ \\
\hline 0 & 25 & 41.0 & 0 & 0.0 \\
\hline 1 & 10 & 57.4 & 10 & 7.1 \\
\hline 2 & 5 & 65.6 & 10 & 14.3 \\
\hline 3 & 7 & 77.0 & 21 & 29.3 \\
\hline 4 & 4 & 83.6 & 16 & 40.7 \\
\hline 5 & 1 & 85.2 & 5 & 44.3 \\
\hline 6 & 1 & 86.9 & 6 & 48.6 \\
\hline 7 & 2 & 90.2 & 14 & 58.6 \\
\hline 8 & 1 & 91.8 & 8 & 64.3 \\
\hline 9 & 2 & 95.1 & 18 & 77.1 \\
\hline 10 & 2 & 98.4 & 20 & 91.4 \\
\hline 12 & 1 & 100.0 & 12 & 100.0 \\
\hline Total & 61 & & 140 & \\
\hline
\end{tabular}


Table 4: Gini Coefficients for Stops, Searches and arrests

\begin{tabular}{|l|l|}
\hline & Gini coefficient \\
\hline Stops & 0.397 \\
\hline Searches & 0.522 \\
\hline Arrests & 0.657 \\
\hline
\end{tabular}

Table 5: Sex of Officer and Sex of Last Person Stopped and Searched

\begin{tabular}{|c|c|c|c|c|}
\hline \multirow{2}{*}{\multicolumn{2}{|c|}{ 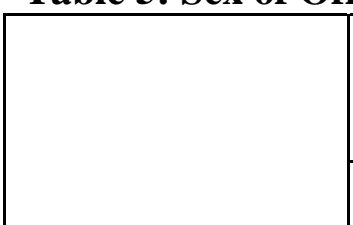 }} & \multicolumn{2}{|c|}{$\begin{array}{l}\text { Sex of last person } \\
\text { stopped and } \\
\text { searched }\end{array}$} & \multirow[b]{2}{*}{ Total } \\
\hline & & Male & Female & \\
\hline \multirow{2}{*}{$\begin{array}{l}\text { Sex of } \\
\text { officer }\end{array}$} & Male & 48 & 1 & 49 \\
\hline & Female & 8 & 8 & 16 \\
\hline \multicolumn{2}{|l|}{ Total } & 56 & 9 & 65 \\
\hline
\end{tabular}

